\title{
ANALISIS MULTIREPRESENTASI MAHASISWA PGSD PADA KONSEP GELOMBANG DAN BUNYI
}

\author{
Siti Fatimah \\ Universitas Sebelas Maret FKIP PGSD Kampus VI Kebumen \\ stfatimah89@gmail.com
}

\begin{abstract}
Waves and sound are included in physics subjects material that contains many graphics and mathematical equations. Hence, students need an effective way to understand it in the form of representation. One of the representation main functions is guiding the student to achieve an indepth understanding. A research was about an analysis of the undergraduate student's multiple representation ability on the material of sound and waves has been conducted. This research involved 148 students from PGSD study program. The results indicated that students have good representation abilities in verbal mode only, while the mathematical and visual representations are needed to be developed.
\end{abstract}

Keywords: Multiple Representation, Waves and Sound.

\begin{abstract}
ABSTRAK
Gelombang dan bunyi adalah salah satu materi fisika yang memuat banyak gambar dan persamaan matematis. Sehingga dibutuhkan cara untuk memahami konsep gelombang dan bunyi dengan bentuk representasi. Salah satu fungsi utama representasi adalah sebagai pembangun pemahaman secara mendalam. Telah dilakukan penelitian tentang analisis kemampuan multirepresentasi mahasiswa pada konsep gelombang dan bunyi kepada mahasiswa prodi PGSD sebanyak 148 mahasiswa. Hasil menunjukkan bahwa mahasiswa hanya memiliki kemampuan representasi yang baik dalam bentuk verbal, sedangkan kemampuan representasi matematis dan visual perlu dikembangkan.
\end{abstract}

Kata Kunci: Multirepresentasi, Gelombang dan Bunyi. 
175 | Premiere Educandum, Volume 6 Nomor 2, Desember 2016, 174 - 179

\section{A. PENDAHULUAN}

Materi IPA khususnya fisika merupakan salah satu materi yang dianggap sulit untuk dipahami dan menakutkan bagi mahasiswa. Salah satu faktor utamanya adalah materi fisika mengandung banyak persamaan matematis dan analisis konsep fisis yang sulit dipahami. Hal ini dibuktikan dengan hasil dokumentasi materi IPA khususnya fisika pada konsep gelombang dan bunyi yang menghasilkan bahwa $86,48 \%$ mahasiswa menyatakan bahwa konsep gelombang dan bunyi merupakan konsep yang sulit dipahami. Penelitian Devetak, 2004;Chittleborough \& Tregust, 2007; Orgill, MaryKay \& Sutherland, 2008 dalam Sarwanto (2013) menyebutkan bahwa umumnya mahasiswa yang performanya bagus dalam ujian, tetapi mengalami kesulitan dalam IPA akibat ketidakmampuan memvisualisasikan struktur dan proses pada level submikroskopik dan tidak mampu menghubungkannya dengan level representasi IPA yang lain. Menurut Reif dalam Murtono (2014), penguasaan konsep merupakan bagian yang sangat penting yang harus dimiliki oleh peserta didik ketika mempelajari fisika dan untuk memecahkan masalah-masalah fisika. Salah satu cara untuk mengetahui penguasaan konsep mahasiswa adalah dengan menyusun penilaian (assesmen) yang sesuai dengan karakteristik ilmu fisika. Menurut Benyamin Bloom dalam Murtono (2014), agar peserta didik dapat melakukan proses pembelajaran yang bermakna, perlu dikembangkan dan dilaksanakan assesmen secara komprehensif, terus menerus, dan objektif. Multirepresentasi mampu mengakses penguasaan konsep dalam bentuk representasi yang berbedabeda. Menurut Vaughan Prain, dkk (2009), multirepresentasi mampu mewakili konsep yang sama dengan mode representasi yang berbedabeda. Mode representasi yang berbeda-beda ini mampu mewakili dalam proses ilmiah, penemuan, dan penjelasan. Mode representasi dapat berbentuk verbal, diagram, gambar, dan gerak tubuh. Sedangkan menurut Waldrip, dkk (2007) representasi dapat dilakukan melalui berbagai bentuk yaitu verbal, gambar, grafik, 
dan matematis. Sehingga dapat dianalisis bahwa bentuk representasi yang sesuai dengan karakteristik materi fisika adalah verbal, visual, dan matematis. Menurut Ainswort dalam Murtono (2014), multirepresentasi memiliki tiga fungsi utama yaitu sebagai pelengkap dalam proses berfikir dan kognitif peserta didik dalam mendapatkan konsep yang lebih sempurna, sebagai pembatas

kemungkinan-

kemungkinan kesalahan dalam menginterpretasikan sebuah konsep fisika, dan sebagai pembentuk pengetahuan untuk mendorong peserta didik membangun pemahaman konsep secara mendalam. Dilanjutkan menurut Murtono (2014) bahwa representasi merupakan proses pembentukan, abstraksi dan pendemonstrasian pengetahuan fisika. Model representasi yang digunakan sebagai asesmen dapat membantu pemahaman dan pemecahan masalah pada konsep-konsep fisika.

\section{B. METODE PENELITIAN}

Data penelitian ini diambil dengan metode ex post-facto yaitu mengambil data dari gejala-gejala yang sudah ada atau telah terjadi, sehingga tidak ada perlakuan. Penelitian ex post facto adalah penelitian yang dilakukan untuk meneliti peristiwa yang telah terjadi dan kemudian merunut ke belakang untuk mengetahui faktor-faktor yang dapat menyebabkan timbulnya kejadian tersebut (Sugiyono, 2008: 9). Subjek penelitian ini adalah mahasiswa PGSD UNS Kampus Kebumen semester 3 dan 5 tahun ajaran 2016/2017 sebanyak 148 mahasiswa dan telah menerima materi gelombang dan bunyi. Instrumen yang digunakan adalah lembar assesmen multirepresentasi bentuk pilihan ganda dengan 15 butir soal disertai dengan alasan terbuka . Data dianalisis dengan menggunakan persamaan:

$\mathrm{KM}(\%)=\frac{\text { Jumlah } \text { skor yang didapatkan }}{\text { skor } \text { maksimal }} \times 100 \%$ Hasil analisis dibandingkan dengan tabel kriteria seperti pada Tabel 1 . 
177 | Premiere Educandum, Volume 6 Nomor 2, Desember 2016, 174 - 179

Tabel 1. Kriteria Kemampuan Multirepresentasi (KM)

\begin{tabular}{cc}
\hline $\begin{array}{c}\text { Rerata Skor } \\
(\mathbf{\%})\end{array}$ & Kriteria \\
\hline$>75-100$ & $\begin{array}{c}\text { Sangat Baik } \\
(\mathrm{SB})\end{array}$ \\
\hline$>50-75$ & Baik (B) \\
\hline$>25-50$ & Tidak Baik (TB) \\
\hline $0-25$ & $\begin{array}{c}\text { Sangat Tidak } \\
\text { Baik (STB) }\end{array}$ \\
\hline
\end{tabular}

(Eko Putro W, 2012)

\section{HASIL PENELITIAN DAN PEMBAHASAN}

Berdasarkan hasil analisis tes mengenai kemampuan multirepresentasi mahasiswa didapatkan data seperti pada Tabel 2.

Tabel 2. Ringkasan hasil tes kemampuan multirepresentasi mahasiswa

\begin{tabular}{|c|c|c|}
\hline $\begin{array}{l}\text { Kemam } \\
\text { puan } \\
\text { Represe } \\
\text { ntasi }\end{array}$ & $\begin{array}{c}\text { Persentase } \\
\text { Ketercapai } \\
\text { an } \\
\text { Indikator }\end{array}$ & Kriteria \\
\hline Verbal & 61,08 & Baik \\
\hline Visual & 49,32 & $\begin{array}{l}\text { Tidak } \\
\text { Baik }\end{array}$ \\
\hline $\begin{array}{l}\text { Matemat } \\
\text { is }\end{array}$ & 40,27 & $\begin{array}{l}\text { Tidak } \\
\text { Baik }\end{array}$ \\
\hline $\begin{array}{c}\text { Rata- } \\
\text { Rata } \\
\text { Kemam } \\
\text { puan } \\
\text { Multire } \\
\text { presenta } \\
\text { si }\end{array}$ & 50,22 & Baik \\
\hline $\begin{array}{r}\text { Tabel } \\
\text { kemampua }\end{array}$ & $\begin{array}{r}2 \text { menjelaska } \\
\text { representasi }\end{array}$ & $\begin{array}{r}\text { an bahwa } \\
\text { verbal }\end{array}$ \\
\hline $\begin{array}{l}\text { mahasiswa } \\
\text { gelombang } \\
\text { nersentase }\end{array}$ & $\begin{array}{l}\text { PGSD pada } \\
\text { dan bunyi men }\end{array}$ & $\begin{array}{l}\text { konsep } \\
\text { aghasilkan }\end{array}$ \\
\hline
\end{tabular}

menunjukkan bahwa mahasiswa PGSD lebih memiliki perhatian kepada bentuk soal yang berbentuk verbal (definisi, konsep, fakta) daripada bentuk soal gambar atau perhitungan.

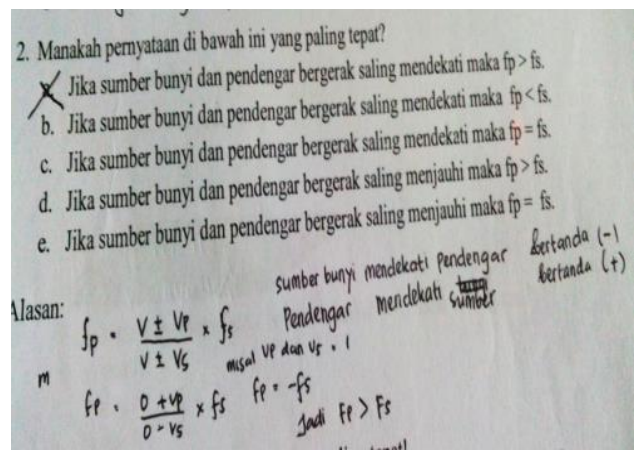

Gambar 1. Contoh lembar soal dan jawaban mahasiswa pada indikator kemampuan representasi verbal.

Menurut Yusup (2009), untuk representasi verbal merupakan cara yang tepat dalam menjelaskan suatu definisi atau konsep. Sedangkan kemampuan representasi visual dan matematis menunjukkan kriteria yang rendah (tidak baik). Berdasarkan hasil interview, mahasiswa masih mengalami kesulitan dalam memahami persamaan. Khususnya pada persamaan efek doppler dan intensitas bunyi. Perhitungan dalam konsep efek doppler memerlukan analisis yang tajam dalam menentukan besaran fisika yang diketahui. Jika tidak dapat menganalisis dengan tajam sebagai 
contoh pendengar atau sumber bunyi yang mendekat atau menjauh, maka persamaan akhir dan hasil tentu tidak akan menghasilkan jawaban yang tepat. Selain harus dapat menganalisis soal dengan baik, proses perhitungan sangat ditentukan dari ketelitian mahasiswa. Mulai dari hasil akhir sampai penentuan satuan dalam jawaban. Hal-hal tersebut menjadi keluhan bagi banyak mahasiswa dalam memahami konsep IPA (fisika) khususnya konsep yang berhubungan dengan perhitungan.

Selain konsep yang berhubungan dengan persamaan matematis, konsep-konsep IPA khususnya fisika mahasiswa masih mengalami kesulitan dalam menganalisis gambar. Namun, untuk tabel mahasiswa masih bisa mengerjakan dengan baik dan benar. Berdasarkan hasil interview, mahasiswa masih banyak yang mengalami kesulitan dalam memahami bentuk soal gambar konsep efek doppler. Mayoritas mahasiswa dalam memahami konsep gelombang dan bunyi masih mengalami kesulitan pada konsep efek doppler.

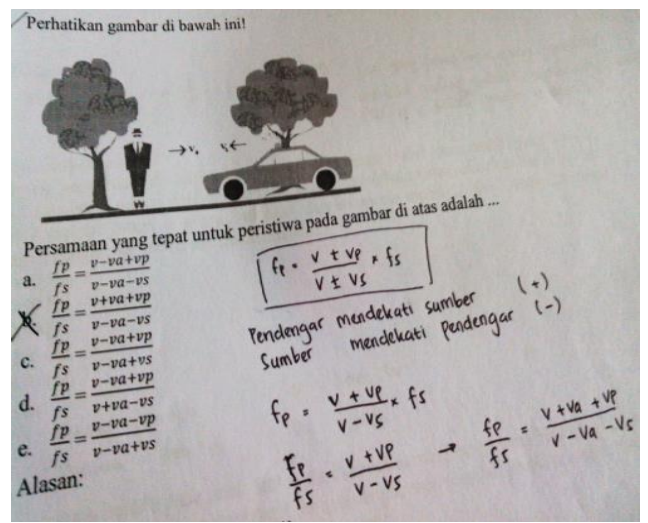

Gambar 2. Contoh lembar soal dan jawaban mahasiswa pada indikator kemampuan representasi visual

Berdasarkan Gambar 2, pemahaman konsep mahasiswa tentang efek doppler dengan representasi visual menunjukkan jawaban yang tidak tepat dan alasan yang tidak tepat. Meninjau alasan pada jawaban tersebut dijelaskan tidak adanya penjelasan tentang pengaruh kecepatan angin. Sehingga dapat dipastikan bahwa mahasiswa tidak mengetahui pengaruh kecepatan angin dalam efek doppler. Meskipun dalam menjelaskan persamaan efek doopler sacara umum benar, namun tidak lengkap sehingga alasan jawaban menjadi tidak tepat.

Kemampuan representasi dalam konsep IPA menjadi satu hal yang penting bagi mahasiswa karena karakteristik materi IPA yang selain abstrak juga mengandung banyak 
179 | Premiere Educandum, Volume 6 Nomor 2, Desember 2016, 174 - 179

perhitungan. Sehingga mahasiswa

diharapkan mampu memiliki

kemampuan multirepresentasi.

Kemampuan representasi menjadi hal yang penting karena mampu membantu melengkapi proses kognitif dan mampu mendorong siswa membangun pemahaman terhadap situasi secara mendalam (Yusup, 2009).

\section{SIMPULAN DAN SARAN}

Berdasarkan hasil penelitian menghasilkan bahwa pada konsep gelombang dan bunyi, kemampuan representasi verbal mahasiswa sebesar $61,08 \%$ dengan kriteria baik; kemampuan representasi visual mahasiswa sebesar 49,32\% dengan kriteria tidak baik; dan kemampuan representasi matematis mahasiswa sebesar 40,27\% dengan kriteria tidak baik. Dalam membangun kemampuan representasi mahasiswa diperlukan analisis pembuatan assesmen representasi yang sesuai dengan karakteristik materi fisika. Selain itu pendidik diharapkan membangun kemampuan representasi dalam pembelajaran IPA khususnya fisika misalnya menggunakan metode eksperimen.

\section{DAFTAR RUJUKAN}

Eko Putro W. 2012. Teknik Penyusunan Instrumen Penelitian. Yogyakarta: Pustaka Pelajar.

Murtono, dkk. 2014. Fungsi Representasi dalam Mengakses Penguasaan Konsep Mahasiswa. JRKPF UAD Vol.1 (2). Hlm. 80-84.

Sarwanto. 2013. Analisis Kemampuan Representasi Mahasiswa Pendidikan Sains PPS UNS. Jurnal Materi dan Pembelajaran Fisika (JMPF) Vol. 3 (2). Hlm. 1-6.

Sugiyono. 2008. Metode Penelitian Kunatitatif Kualitatif dan $R \& D$. Bandung. Alfabeta.

Yusup. 2009. Multirepresentasi dalam Pembelajaran Fisika. Diseminarkan pada Seminar Nasional FKIP UNSRI tanggal 14 Mei 2009 di Palembang.

Vaughan Prain, dkk. 2009. Multiple Representation in Learning About Evaporation. International Journal of Science Education. Vol 31 (6).

Waldrip, B., V. Prain \& Carolan. 2007. Learning Junior Secondary Science through Multi-Modal Representations. Electronic Journal of Science Education Preview Publication. Vol. 11, No. 1. 